\title{
Entry Assessment in Community Colleges: Tracking or Facilitating?
}

\section{Mary E. Kingan \\ Richard L. Alfred}

Maria Lopez is returning to school after 17 years. When she graduated from high school, she received a scholarship to the local university. But Maria felt pressured by her family to marry and have children. Now she wants a better job, and she wants to contribute financially to her family. Maria cannot afford the tuition at a university, so she is enrolling at a community college. Her husband and four children do not understand why she wants to go to college; none of the other women in the family have gone to college. In fact, only one of the men in the family went to college. Maria feels unsure of herself and her abilities. Given any excuse, she probably will quit and return to her comfortable and predictable world. What are her chances of succeeding in higher education and at the community college? The college will most likely require her to take a battery of assessment tests before she can register for classes. Will these tests automatically track her into a curriculum that is not of her choosing--one that offers access to a career but not the baccalaureate degree?

For years, educators considered tracking to be beneficial. A considerable amount of evidence now suggests quite the contrary in public, primary, and secondary schools (Slavin, 1987; Esposito, 1973). According to Oakes,

We have virtually mountains of evidence indicating that homogeneous grouping doesn't consistently help anyone learn better. Over the past 60 years, hundreds of studies have been conducted ... [that] vary in their size and in their methodology. ... . The results differ in certain specifics, but one conclusion emerges clearly: No one group of students has been found to benefit consistently from being in a homogeneous group. (Oakes, 1985, p. 7) 
This article addresses the issue of entry assessment. Does testing and assessment of entering students begin the cycle of tracking students into curricula that limit future educational opportunities, job options, and salaries? Or does entry assessment provide opportunities for students by encouraging the development of the fundamental skills necessary for educational and career advancement? Those who debate this issue do so with vigor. It is essential to sort emotionally charged rhetoric from reasoned inquiry.

\section{Entry Assessment: An Economic Perspective}

Institutions administer assessment tests to entering students in order to ascertain students' readiness for college-level work and to determine the appropriate program placement. Most community colleges use nationally recognized standardized tests, although some add their own testing procedures. Based on test results, counselors or administrators advise students on appropriate classes. It is this advising process that scholars often term as "tracking."

The issue of tracking has come to the forefront, in part, because of the changing economic situation in the United States. In the 1970 s, $75 \%$ of the U. S. population fell within the middleincome level. But by 1985 , that percentage had fallen to $67 \%$ (Panel Study of Income Dynamics, 1992, p. 1). Economic conditions for the middle class have darkened in recent years as the recession has forced a sharp downturn in employment, particularly in the service industries. At the same time, the cost of higher education has risen steadily, creating important consequences for community colleges. According to Templin, "middle-class students faced with increased costs and higher admissions criteria in some four-year colleges and universities are likely to consider community colleges an acceptable option" (1983, p. 41). This trend would suggest a changing orientation among middle-class students toward community colleges as "institutions of choice."

An article in a recent issue of the Chronicle of Higher Education acknowledges this orientation by identifying the changing role of community colleges as a conduit to the baccalaureate degree (Mercer, 1992). According to Mark Krousse, a consultant to a California assemblyman, "When you can educate somebody for less at the community colleges, where the student-teacher ratio is better and you have more contact with the professors, there don't seem to be many reasons for not offering baccalaureate degrees at some two-year colleges" (Mercer, 1992, p. A28).

Women and minorities traditionally dominate the community college population (Monk-Turner, 1990). As the economic 
factors associated with community college attendance have changed, those who traditionally have looked to community colleges as their threshold for entering higher education (women, minorities, and students with working class backgrounds) now may feel compelled to compete with middle class high-school graduates who are using community colleges as a low-cost alternative for completing the first two years of college. This situation may track certain groups of students into alternative or second-choice curricula. Although tracking stands as an issue worthy of examination in its own right, the problems associated with channeling students into second-choice curricula as an outcome of the changing student population put the issue on virtually every institution's agenda.

In this article, we refer to tracking as the grouping of students into separate classes according to ability, usually executed by one of two methods. In the first method, all students follow a similar curricular program, but each student is grouped into a class at his or her particular achievement level. The second method streams students into completely different curricular programs. Most tracking from entry assessment in community colleges falls into the second category where the institution separates students into homogeneous instructional groups based on assumed similarities of ability or aptitude.

\section{Assessment As Tracking}

Those who claim that entry assessment in community colleges leads to tracking do so for a variety of reasons. Opponents of assessment most often mention testing bias and the questionable reliability and validity of the testing instruments as serious drawbacks. These criticisms stem from four major themes. First, the rapid growth of the testing movement in the last decade has brought more sophisticated measurement and testing possibilities to higher education. In reaction, the public has become wary of the increasing sophistication of tests and test results. Second, because the methods for addressing the possible shortcomings of tests remain complex and varied, monitoring the testing instruments can prove difficult, thereby increasing public distrust. Third, in response to public suspicion, legislators make legal decisions regarding discriminatory practices that "continue to affect how testing research is done and continue to put pressure on educators and policy makers to improve assessment and placement procedures" (Kanter, 1990, p. 3). Fourth, comparative studies show a difference in the performance of minorities (compared to nonminorities) as measured by placement tests. Minorities, as a group, score lower on standardized tests (Kanter, 1990, p. 3). 
The state of Texas provides an interesting example of objections to assessing entering community college students on the basis of biased tests. All entering, first-time students to higher education in Texas must take the Texas Academic Skills Program (TASP) test. If the students do not pass all sections satisfactorily, they must complete remedial education courses before enrolling for college-level work. The Mexican American Legal Defense in Education Fund (MALDEF) has challenged the development of the TASP test on the grounds that, due to the questionable accuracy of the test, minority students consistently receive lower scores and thus begin a different educational track (Angel, 1990).

Most critics of entry assessment oppose it on the grounds that testing most adversely affects minorities who need the educational opportunities community colleges offer. This argument begins with the premise that, "It is not enough to provide minorities with additional years of schooling, they must receive a quality education" (Monk-Turner, 1990, p. 719). Critics point out that the relative gains in minority earnings since 1960 have come more from institutional quality and the type of educational program than from additional years of schooling (Link \& Ratledge, 1975). In the words of Karabel, the distinction is "not who gains access, but what happens to people once they get there" (Karabel, 1972, p. 553).

A study utilizing 1,062 men and women in the National Longitudinal Survey of Labor Market Experiences suggests that attainment of a baccalaureate degree remains important in terms of future occupational attainment, especially for minorities (Monk-Turner, 1990). Therefore, if entry assessment leads minorities into nontransfer programs, the institution contributes little help to these students who use the community college as their door to higher education and economic opportunity.

Karabel, one of the leading opponents of tracking in community colleges, asserts that in 1972 more than $70 \%$ of students entering community colleges aspired to achieve a baccalaureate degree, but less than $50 \%$ of them reached a fouryear institution. And only $20 \%$ of those students received a baccalaureate degree (Karabel, 1972, p. 531). In the United States, most citizens achieve social and economic goals through the system of public education. However, contrary to popular perceptions, "American and European rates of social mobility, at least measured by mobility from manual to nonmanual occupations, remain very similar" (Karabel, 1972, p. 522).

Using economic mobility rates as an indicator, some critics assert that community colleges are changing into middle-class institutions, but they may be doing so at the expense of minorities. The odds remain strong that minorities placed into remedial education courses will not be any better off academically after their community college experience than they were before they 
had the experience (Moore, 1970; Templin, 1983). In community colleges, the argument follows, equal access does not lead to equal outcomes or results. And the "unequalizing" process begins with entry assessment.

Another common criticism of entry assessment in community colleges involves the limited database for identifying skillsdeficient students. Critics who use this argument claim that most community colleges do not maintain sufficiently accurate information to determine the specific skills needed for certain courses as determined by test scores of preceding student cohorts in relationship to their actual achievement in college courses (Callas, 1987).

A study of 6 two-year colleges in the state of New York showed that faculty and staff in several of the schools did not establish clear relationships between remedial education courses and the college-level curriculum (Callas, 1987). The absence of a clear sequence of courses, critics of entry assessment claim, leads students who begin in remedial education courses to a revolving door with little opportunity for college-level work and expansion of economic opportunities. Rather than send the students through a poorly understood system, counselors or administrators may enroll students in occupational courses that do not require basic skills proficiency.

This tracking or "cooling-out" process begins even before the students arrive. If the assessment tests reflect poorly on students' abilities, counselors and advisors respond by suggesting a "realistic" program. As skills-deficient students review their test scores with an advisor, they may develop negative self-images. Although difficult to measure, negative self-images can create academic problems for students. Students may feel ashamed to take classes or to attend labs for "slower " students, and this stigma can hinder their achievement. One student from the Washington, D.C. area explained the students' perspective as follows:

It really don't have to be the tests, but after the tests there shouldn't be no separation of the classes. Because, as I say again, I felt good when I was with my class, but when they went and separated us--that changed us. That changed our ideas, our thinking, the way we thought about each other and turned us to enemies toward each other-because they said I was dumb and they were smarter. (Mecca, 1992, p. 62)

\section{Assessment As Constructive Assistance}

However, according to Bray, entry assessment helps community colleges provide the type of support that skilldeficient students need (Bray, 1987). Assessment systems will 
continue to emerge as key institutional support mechanisms. In fact, most community colleges assert that students benefit from assessment (Boggs, 1984; Astroth \& Weber, 1988; Hobbs, 1989; Hodges, 1990; Lyons, 1990). These studies indicate that entry assessment tests help. Students who enroll in remedial education courses (as the assessment tests suggest they should) consistently perform better than those who choose not to enroll in remedial courses. Therefore, entry assessment tests give students a better chance of success in a community college, regardless of their academic program.

In order to curb the possible testing biases in assessment procedures, many community colleges now require different kinds of assessment information from each student (Bray, 1987; Rounds \& Anderson, 1984; Olson \& Martin, 1990). Information collected at entry includes prior educational record, general and specific aptitudes, and nonintellectual or noncognitive personal characteristics that affect scholastic readiness (Lunneborg, 1977). Some colleges take this process a step further by administering a wide variety of personality, scholastic, and personal aptitude tests and assessment procedures at no cost.

Most community colleges now keep detailed records of students' test scores and required scores for college-level courses. Community colleges that administer standardized tests (such as the ASSET test) receive fully integrated and correlated reports within hours of test completion via computer. These systems make monitoring student progress easier and allow close scrutiny of assessment policies and procedures.

Proponents of entry assessment in community colleges point to the fact that many remedial courses require work similar to and (in some cases) equal to college-level work. The National Institute of Education sponsored two studies of literacy in community colleges; the researchers reported similar findings in each study. Community college remedial education courses require students to "do more reading, writing and figuring . . . than regular course work" (Roueche, Baker, \& Roueche, 1985, p. 5). Researchers such as Richardson, Fisk, and Okuin (1983) challenged this assertion with research that questions the quality and rigor of remedial coursework. Many students are not being challenged, and literacy demands on two-year college students fall short of what is needed to prepare them for college-level work. On balance, the rigor of remedial courses and the way they are used by students vary from course to course and student to student. What works for one course or student may not work for another.

\section{Helping Students Succeed}

With arguments against entry assessment as tracking and arguments for it as constructive assistance, how can community 
colleges expand students' choices after remedial education? Guilford Technical Community College in North Carolina has implemented an entry assessment program that requires students to meet with academic advisors before and after remedial education courses (Corwin, 1986). Figure 1 illustrates the process.

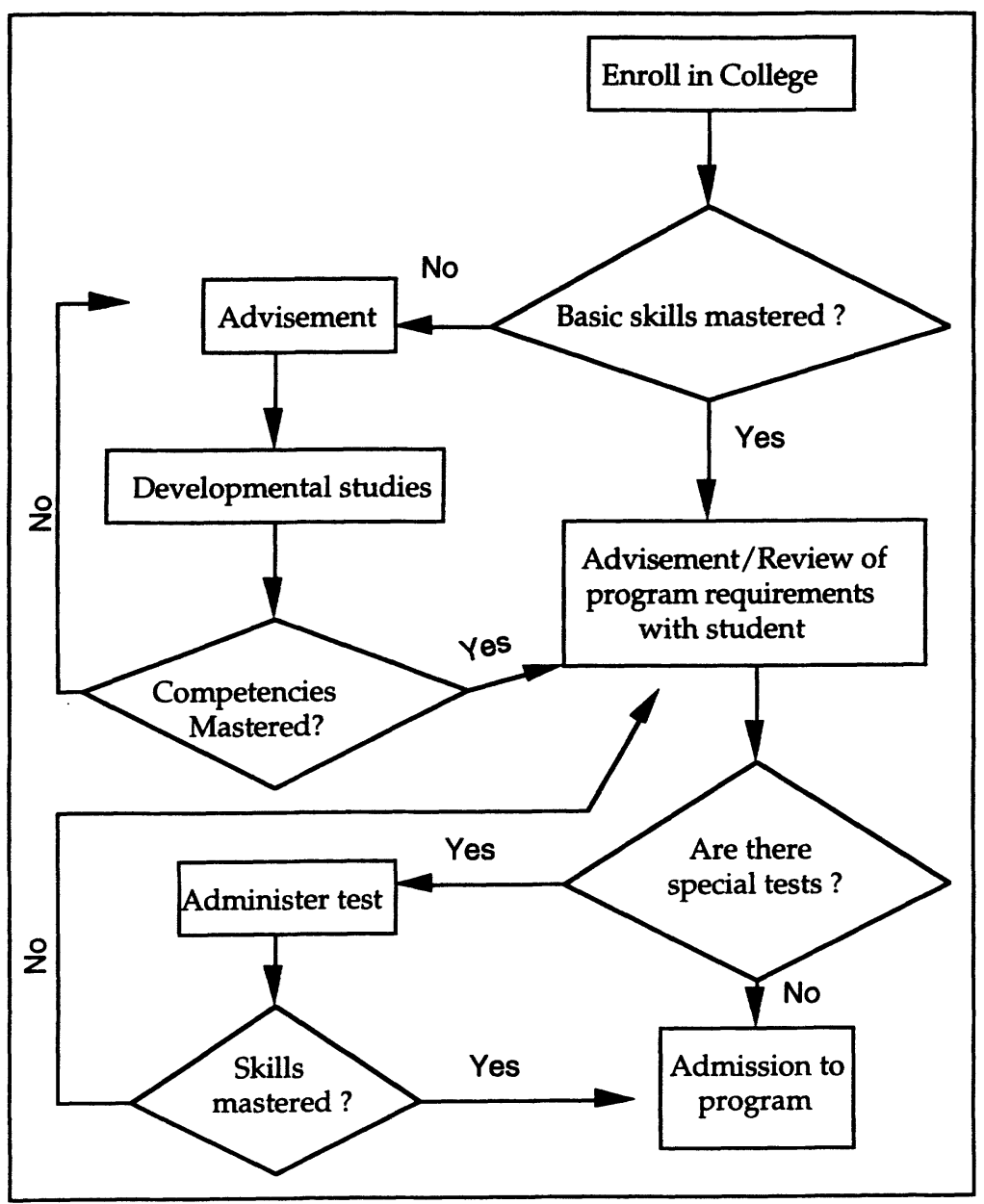

Figure 1. Guilford Technical Community College Entry Assessment Program. 
Advisors follow students through the assessment process, giving practical advice and support in all aspects of decisionmaking. If students do not need remedial education courses, they can attend the program of their choice immediately. However, if students do need remedial education, they meet with the advisor to discuss program options after completing the prescribed remedial courses. At this point, the options of skills-deficient students and non-skills-deficient students are equal. No differences exist.

Colleges utilizing assessment procedures such as the Guilford program consistently report substantial long-term benefits for students in classroom performance and persistence rates. For example, Tacoma Community College in the state of Washington tracked the success of students whose assessment test scores indicated a need for remedial coursework. Of those who chose remedial education, $75 \%$ passed all coursework. In contrast, only $35 \%$ of those who refused remedial education courses passed all coursework (Spangler \& Simpson, 1981, p. 3).

Similarly, Broward Community College in Florida conducted research to ascertain if student performance on placement tests and enrollment in remedial education courses affected graduation and persistence rates. The results indicated that those who completed remedial education courses achieved higher retention and graduation rates than those who did not complete remedial education courses. The study also found that $86 \%$ of the students who completed two remedial education courses completed a degree program, whereas only $36 \%$ of those who did not take remedial education courses completed a degree program (Gabe, 1989 , p. 1). A comprehensive study by Lum in 1985 of 10,000 students enrolled in remedial writing courses noted results consistent with these findings. Taking and successfully completing remedial courses greatly enhanced students' chances of program completion (Lum, 1985).

The Community College Consortium, a cooperative of community colleges and universities working together to improve community college effectiveness, has proposed an inducementbased model for delivering academic and support services that elaborates on the theme of enhancing student success through entry assessment (Alfred, Peterson, \& White, 1992). This model proposes a structure for support services that juxtaposes academic programs and support services in such a way that they complement one another. Assessment becomes one step in a complete process that encourages students to affiliate with college faculty and staff (Figure 2). The value of this model rests in its recognition that programs and services must be organized flexibly to meet student needs.

Student achievement that leads to successful outcomes is best accomplished through an orientation that prevents negative outcomes from occurring. A prevention orientation means that 
administrators, faculty, and staff need to become increasingly proactive. They must use their skills and experience to design intervention strategies for such potentially vulnerable student populations as single parents, returning adult learners, underprepared learners, and unemployed workers. Such strategies can include programs to strengthen self-esteem, build confidence, and improve competence and coping skills through outreach efforts that are carefully crafted to meet identified needs (Alfred, Peterson, \& White, 1992).

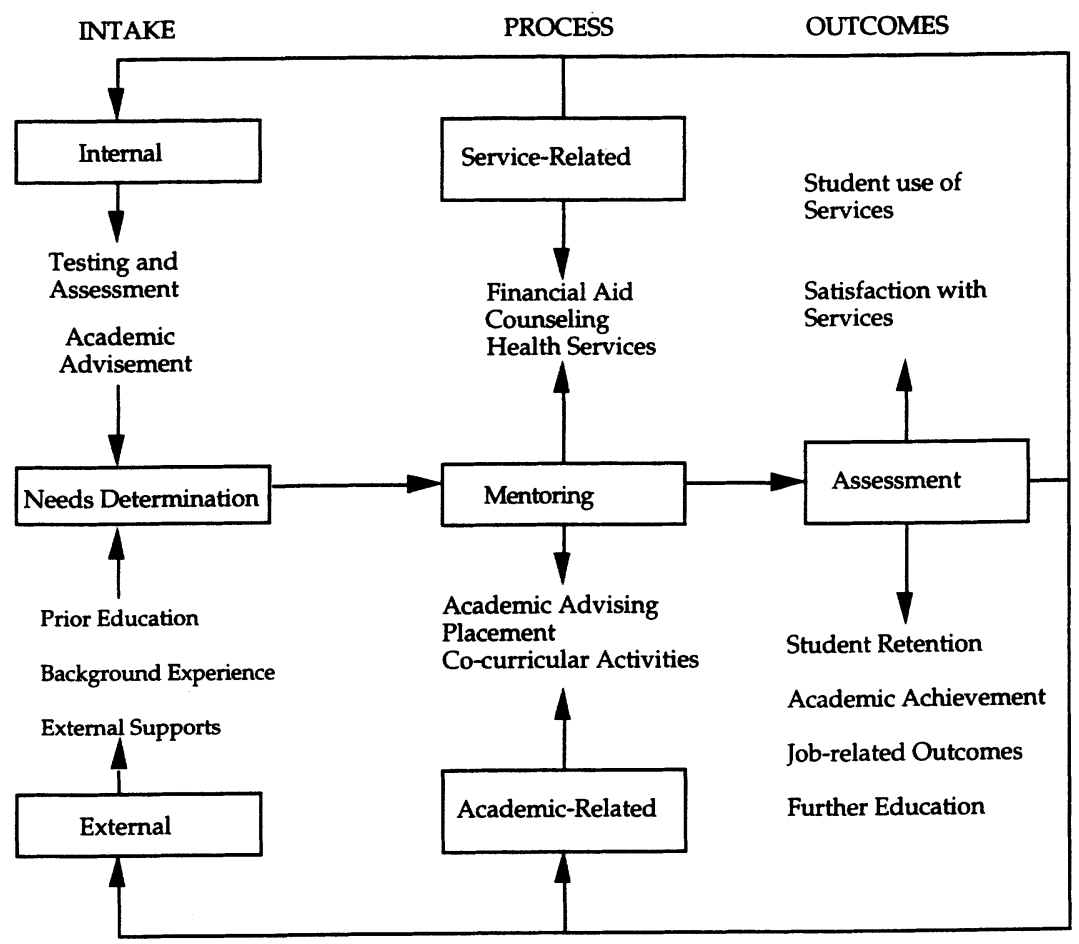

Figure2 Inducement-based model for delivering support services.

Unfortunately, without an infrastructure in place to carry out an aggressive program, this prevention approach is not possible. Support services in community colleges are organized along functional lines of academic and student services. Little communication and minimal integration exists among these services and between the services and academic departments. 
Students bring complex problems to community colleges, but they experience fragmented and compartmentalized responses.

Students involved in special programs typically experience a different situation. Over time, services for special populations, such as handicapped and adult learners who may be particularly at-risk for not completing their education, have been integrated across functions with program coordinators acting as advocates for specific groups. Students in these groups feel supported; they have a sense of belonging to the institution.

Community colleges need to carry out entry assessment as one element in a program that connects students and institutions by reaching out through aggressive services. In the Community College Consortium model, support services such as testing, entry assessment, and admissions counseling are used to determine the position and needs of the learner in relationship to the institution. In the first stage of the model, the Intake Stage, four questions are addressed and answered:

Is the student academically and socially prepared for college?

What is the student's previous experience with education, and when did this experience occur?

What external supports does the student have to facilitate or retard success (including financial assets, family support, work environment, etc.)?

What specific needs (academic and nonacademic) does the student have that must be addressed to improve the chance for success?

The second stage of the model begins with mentoring, a process designed to match students' needs with the college's important features. Labeled the Process Stage, the objective of support services in this stage is to meet student needs inside and outside of the classroom based on information acquired earlier. Critical processes in this stage center on connecting each student to a recognized member of the college community--a faculty member, student development professional, or staff member--who can serve as a mentor or intermediary. Mentors, counselors, instructors, support service specialists, and academic advisors work together to refer students as needed to specific support services: career and personal counseling, financial aid, health services, and other services such as parking, transportation, and job placement. The support services specialists and academic advisors may make referrals back to the mentor. Through a connection to a member of the college community, each student will have access to and be 
a part of a network of services and programs that make up an integrated system.

The third stage in the model, Outcomes, focuses on assessment as a method for determining the impact of support services on students. This stage involves research to determine the extent to which services are used, how satisfied students are with them, and the relationship of services to outcomes in work and further education. Using the results of research to improve services means adjusting class schedules, class locations, and program offerings, as well as instructor, counselor, and business office hours to accommodate student work schedules and needs. It also means changing to a prevention orientation in academic advising, career and personal counseling, learning resource centers, and student services.

Such services as child care and transportation may also be provided or adjusted to meet the special needs of commuting students. In other words, services will be provided to students at times and places that are convenient for them, and by staff who understand their needs and can help them achieve important goals. A comprehensive assessment of current services using this model is an important step for community colleges. Restructuring the delivery of support services to accommodate student needs and to promote success is essential to the future of our colleges; it is also a critical challenge to faculty and staff.

With innovative support services models and with new electronic grading and reporting systems, administrators can utilize entry assessment to aid students and service units. For example, the financial aid information gathered during assessment can indicate possible award recipients. Counseling information on individual student's abilities or educational shortcomings can help counselors with the important job of guiding students into courses and programs. Job placement information on students' specific strengths and interests can aid job placement coordinators in successfully matching prospective employees with appropriate work settings. Transfer assistance administrators can utilize entry assessment data to help students with successful transfer. Knowledge of particular strengths and interests can aid a student in choosing an appropriate institution and field of study.

\section{Conctusion}

To return to the original scenario, what are Maria's chances of succeeding at the community college in light of the fact that she must take an assessment test? Most of the evidence suggests that Maria stands a better chance of success at the community college if she takes an assessment test. Although she may fear the test and doubt herself, she most likely will not persist if she is academically underprepared for college-level work and receives no remedial 
help. She may become overwhelmed and find convenient and understandable excuses for withdrawal. However, if the assessment test reveals that she needs help with basic skills, she probably will receive the necessary aid through remedial education courses, thus increasing her chances of persistence. Moreover, if she begins in a community college that is reaching out to students through proactive support services, her chances for success will improve beyond those associated with entry testing.

The primary reason that Maria's chances improve with entry assessment lies in the improved assessment procedures and support services at many community colleges. The assessment test, in and of itself, is not the key to success. Rather, the systematic identification of students in need of remediation, coupled with academic and student support services that include a strong faculty and staff component, can make the difference between success and failure (Rendón, 1992).

Procedures for assessment will continue to be a major fiscal, political, and educational issue. Despite opposition against testing as discriminatory, unscientific, and imperfect, entry assessment of students is here to stay. Within the decade, issues related to the amount of time and money spent on test instruments will lessen in importance as the controversy over the amount of money and time spent on advising and follow-up systems increases. As entry assessment practices in community colleges improve, integrating assessment with all aspects of the institution will become an important requirement.

Shortsighted criticism of entry assessment must give way to student-oriented assessment programs that incorporate all aspects of the institution and make full use of assessment data. As public demands for accountability escalate, administrators must pay close attention to assessment procedures because, in the future, effective colleges will use comprehensive entry assessment procedures and implement the results to improve programs and services.

\section{References}

Alfred, Richard L., Peterson, Russell, and White, Theodore. (1992). Making community colleges more effective: Leading through student success. Ann Arbor, MI: Community College Consortium.

Angel, Dan. (1990). Texas Academic Skills Program. (ERIC Document Reproduction Service No. ED 317 226)

Astroth, Jonathan, and Weber, Jerry. (1988). Evaluation of an assessment and placement system for entry-level courses. (ERIC Document Reproduction Service No. ED 297 830)

Boggs, George. (1984). The effect on basic skills assessment on student achievement and persistence at Butte College: A research report. (ERIC Document Reproduction Service No. ED 244 686) 
Bray, Dorothy. (1987). Assessment and placement of developmental and high-risk students. In Kenneth M. Ahrendt (Ed.), Teaching the developmental education student (pp. 33-48). New Directions for Community Colleges, no. 57. San Francisco: Jossey-Bass.

Callas, Dennis. (1987). Academic placement practices: An analysis and proposed model. College Teaching, 33(1), 27-32.

Corwin, Luene, and others. (1986). Assessing students' skills and interests, 1986. National Center for Research in Vocational Education. (ERIC Document Reproduction Service No. ED 275 845)

Esposito, D. (1973). Homogeneous and heterogeneous ability grouping: Principal findings and implications for designing more effective educational environments. Review of Educational Research, 43, 163-79.

Gabe, LiAnne. (1989). College preparatory instruction and student persistence at Broward Community College. (ERIC Document Reproduction Service No. ED 310 822)

Hobbs, Rudy L. (1989). Academic and developmental services: End-of-year status report, 1988-89. (ERIC Document Reproduction Service No. ED 310835 )

Hodges, Daniel, L. (1990). Entrance testing and student success in writing classes and study skills classes. (ERIC Document Reproduction Service No. ED 331 555)

Kanter, Martha J. (1990, April). An examination of demographic, institutional, and assessment factors affecting access to higher education for underrepresented students in the California colleges. Paper presented at the Annual Meeting of the American Educational Research Association, Boston, MA.

Karabel, Jerome. (1972). Community colleges and social stratification. Harvard Educational Review, 42(4), 521-562.

Link, Charles, and Ratledge, Stewart. (1975). Social returns to quantity and quality of schooling. Journal of Human Resources, 10, 78-90.

Lunneborg, Clifford E. (1977). Evaluating student readiness for further education. In Leonard L. Baird (Ed.), Assessing student academic and social progress (pp. 21-35). New Directions for Community Colleges, no. 18. San Francisco: Jossey Bass.

Lum, Glen. (1985). Compulsory and voluntary remedial writing placement policies, demographic characteristics and student performance in selected community colleges. Unpublished doctoral dissertation, University of Michigan, Ann Arbor.

Lyons, J, Doyle. 1990. Success of community college students completing developmental courses. (ERIC Document Reproduction Service No. ED 325 194)

Mecca, Frank. (1992). Neither equitable nor excellent: The effects of tracking on minority students. In Roy Marshall (Ed.), Securing our future: The importance of quality education for minorities (pp. 47 - 63). Austin, TX: University of Texas. 
Mercer, Joyce. (1992). States turn to community colleges as route to bachelor's degree as four-year year campuses face tight budgets and overcrowding. Chronicle of Higher Education, 38 (35), A1, A28.

Monk-Turner, Elizabeth. (1990). The occupational achievements of community and four-year college entrants. American Sociological Review, 55, 719-725.

Moore, William, Jr. (1970). Against the odds. San Francisco: Jossey-Bass.

Oakes, Jeannie. (1985). Keeping track: How schools structure inequity. New Haven: Yale University Press.

Olson, Margot, and Martin, Diane. (1990). Assessment of entering student writing skill in the community college. (ERIC Document Reproduction Service No. ED 235 845)

Panel Study of Income Dynamics (PSID). (1992). A study of family economics survey. Ann Arbor, MI: Survey Research Center, Institute of Social Research, University of Michigan.

Rendón, Laura I. (1992). Written correspondence with authors, July 1992.

Richardson, Richard, Fisk, Elizabeth, and Okuin, Morris. (1983). Literacy and the open access college. San Francisco: Jossey-Bass.

Roueche, John E., Baker, George, III, and Roueche, Susan D. (1985). Access with excellence: Toward academic success in college.

Community College Review, 12(4), 4-9.

Rounds, Jeanine, C., and Anderson, Dan. (1984). Assessment procedures: What works and what needs improvement in California community colleges. (ERIC Document Reproduction Service No. ED 252 255)

Slavin, Robert. (1987, Fall). Ability grouping and student achievement in elementary schools: A best evidence synthesis. Review of Education Research, 57, 293-336.

Spangler, Richard C., and Simpson, Carolyn. (1981). The developmental education program at Tacoma Community College. (ERIC Document Reproduction Service No. ED 226 786)

Templin, Robert G., Jr. (1983). Keeping the door open for disadvantaged students. In George B. Vaughan \& Associates (Eds.), Issues for community college leaders in a new era (pp. 39 - 54). San Francisco: Jossey-Bass.

Mary E. Kingan is a graduate student in the Program in Higher and Adult Continuing Education, University of Michigan, Ann Arbor, Michigan.

Richard L. Alfred is Associate Professor of Higher and Adult Continuing Education, University of Michigan, Ann Arbor, Michigan, and Codirector of the Community College Consortium. 